\title{
RARE BOOK ACQUISITIONS
}

\author{
COMPILED BY JANICE A. KRAUS
}

\begin{abstract}
Ms. Kraus is the Curator of Rare Books and Exhibitions in Special Collections and Archives, Alexander Library.
\end{abstract}

This year significant editions have been added to the rare book holdings in Special Collections and Archives, Alexander Library. Generally, the I 988-89 acquisitions fall into four categories, Westerners in the Orient, herbals and botanies, dictionaries and, of course, New Jersey. A map of China from the atlas of Jodocus Hondius (Amsterdam, I6 13) was purchased (Special Collections Endowment Fund). This was the first map of China to appear in a European atlas. It is interesting for its portrayal of China, only recently being explored by European missionaries, most of the country still virtually terra incognita. Japan is also shown and alongside that country is a cartouche with the crucifixion of a Jesuit missionary, a timely reminder of the hazards Europeans faced. In the upper right is shown a bit of the northwest coast of America, with an indigenous deer and fox represented.

The Histoire de l'establissement, des progres et de la decadance du Christianisme dans l'empire du Japon (Louvain, I 828-29), written by Pierre Francois Xavier de Charlevoix, was purchased (Charles H. and Mary Elizabeth Brower Fund). Charlevoix (I682-I76I) was an itinerant French Jesuit who taught in Canada and traveled down the Mississippi River to New Orleans. His work on Japan was first published in I 7 I 5 and was one of the earliest reliable histories of Japan. It was still, as the publication date of the edition attests, used into the nineteenth century. Charlevoix, in the main, used Kaempfer's history of Japan along with Jesuit accounts in manuscript. He also compiled a bibliography of all the works on Japan available in I 7 I 5 .

The monumental work of the Jesuit P.J.B. Du Halde (I 674-I 743), A Description of the Empire of China ... (London, I 738-4I; 3 vols.) was acquired this year. The rare book collection has the first edition of I 735 written in French; with the addition of this, the first English edition, the Libraries now have one of the most influential works on the Orient in its time. It was printed serially and gathered together over a number of years. Its maps and engravings of costumes, city views and ceremonies are invaluable; the maps reveal what advanced cartography was practiced by the Jesuit missionaries. There is also material on Alaska (Gift of the Estate of Samuel Bard; Special Collections Gift Fund). 
Nicolas Trigaut's Due lettere annue della Cina del ${ }_{1} 6_{10}$ e del ${ }_{1} 6_{1}$ (Rome, I6 I 5) is the companion piece and predecessor of a volume already in Special Collections and Archives. Trigaut (1577-1628) was one of Matteo Ricci's companions on the Jesuit Order's first concentrated incursion into China. The letters recount events right after Ricci's death and show that Ricci was not solely responsible for the vitality of the Chinese mission (Charles H. and Mary Elizabeth Brower Fund). The "companion" volume is Trigaut's De Christiana expeditione apud Sinas (Lynn, I6 16). Jacques de Machault's (1600-1680) Relation des missions des peres de la compagnia de Iesus (Paris, I659) is another purchase for the Westerners in the Orient collection. Father Machault's avocation was the writing of historical and geographical accounts of the Jesuit missions in Paraguay, India, Japan, Indochina, among other places (Class of 1943 Fund). J. de la Brune's La morale de Confucius (Amsterdam, I688; Brower Fund) and the Lettre des messieurs des missions etrangeres au Pape, sur les idolatries et les superstitions chinoises (Paris, I 700; Donald R. and Pearl Patterson Thompson Fund), have also been purchased for the libraries. La morale de Confucius is a vastly abridged re-working of Confucius sinarum philosophus (Paris, I 687), a Jesuit-produced study of Confucianism (which also is a part of Special Collections and Archives holdings). The Lettre des missions is a discussion of the native rites controversy in which the Jesuits and the Vatican were at odds.

Viagem da corveta Dom Joas I a capital do Japao (Lisbon, I 863) by Feliciano Antonio Marques Pereira describes the negotiation of a trade treaty with Japan in I 860 by the Portuguese as well as descriptions of Japanese customs, politics, geography and industry (Charles H. and Mary Elizabeth Brower Fund).

Four items have been added to the dictionary collection. The first, by David De'Pomis (I 525-I 593) is the Dittionario novo hebraico (Venice, I 587 ; Donald R. and Pearl Patterson Thompson Fund). This trilingual dictionary, in Hebrew, Latin and Italian, also contains scientific and historical information. John Florio's ( I 553?-I625) Vocabulario italiano Eै inglese (London, I659) is the second edition to be acquired for the Libraries, the previous acquisition dating $\mathrm{I} 688$. This was the standard seventeenth century Italian/English dictionary and was indispensable for the Shakespearean commentator. The final editing was done by Giovanni Torriano, the leading Italian scholar of his day (Special Collections Endowment Fund and Class of r 943 Fund). Henri Estienne's Thesaurus graecae linguae (Geneva, I 572), in four volumes, has been acquired. Estienne publications were always noted for their stringent scholarship (no- 
tably in Greek studies). The fourth item is a fifteenth-century manuscript of Guarino Veronese, the Alphabetum. This apparently unpublished lexicon precedes that of Vegio, considered one of the first.

In the area of herbals and botanies two important items were acquired this year; Pietro Andrea Mattioli's ( I 500-1 577) Dei discorsi nelli sei libri di Pedacio Dioscoride. . . (Venice, I 585), and the De medicinali materia of Dioscorides (Frankfort, I 549). Both are notable for the hand-coloring of the illustrated specimens. The Libraries already hold four other editions of Mattioli's work; the edition of Dioscorides is illustrative of the editions of the ancient scholars which were available for the use of those such as Mattioli who were interested in medical botany and pharmacy. The Dioscorides text was updated and expanded (as were the texts of ancient authors generally) with newly-discovered plant specimens (both volumes were purchased from the Class of I 943 Fund).

Of more general interest are two newly-acquired maps. The first, Das ander alter der Welt, a world map from the I 493 Nuremberg Chronicle is an essentially medieval view of the world, complete with grotesques and a rather sketchy geography (it is hand-colored). The second by V. M. Coronelli (I650-I7I8) is a hemispheric map showing the Americas, printed in Venice in I693 (Class of 1943 Fund). Coronelli's artistry as well as his accuracy in depiction is a feature of all of his publications.

Of New Jersey interest is the acquisition of $A$ Farther Account of EastNew-Jarsey ... (Edinburgh, I683). This promotional tract describing life and conditions in East New Jersey contains a letter from George Lockhart to Robert Barkley (proprietor), with a description of the area by John Ogilbey. This is only the second copy of this tract in the United States; the John Carter Brown Library has the other (Special Collections Gift Fund; Chapman Fund; Frelinghuysen Fund; Hankin Fund). 